быть только уравновешены плюсами других форматов [4]. Кроме того, слияние квестовых форм в рамках одной игры сделает ее, безусловно, богаче и увлекательнее.

$$
* * *
$$

1. Мальшакова Е.С. Квест-маршрут как пример инновации в образовательном туризме // Формирование гуманитарной среды в вузе: инновационные образовательные технологии. Компетентностный подход. Пермь, 2017. Т. 1. С. 439-445.

2. Максимова Д.И. Проблема уличного игрового пространства // Научный поиск в современном мире: сборник материалов XII Международной научно-практической конференции. Махачкала, 2016. С. 179-180.

3. Миновская О.В. Городское приключение в воспитании учащейся молодежи: учебно-методическое пособие. Кострома, КГУ им. Н.А. Некрасова, 2012. 128 с.

4. Гурин В.В. Экскурсионный потенциал игровых квестов для школьников // Инновации в науке и практике. Сборник статей по материалам III Международной научно-практической конференции (10 ноября 2017 г., г. Прага). В 4 ч. Ч.4 / - Уфа: Изд. Дендра, 2017. С. 156-162.

\title{
Доржеева В.B.
}

\section{Административно-правовое положение территорий Российского Северо-Востока} (XVII в. - начало XVIII в. )

Северо-Восточный государственный университет (Россия, Магадан )

doi:10.18411/spc-10-01-2018-11

idsp: 000001:spc-10-01-2018-11

Территориально понятие «Северо-Восток» охватывает тундровые и лесотундровые пространства Чукотского полуострова, лесную зону Приколымья, северное побережье Охотского моря и восточные районы Якутии. Общая площадь около 2 млн. кв. км. В физической географии территория определяется как ЯноЧукотская горная страна, занимающая пространство между реками Леной и Анадырем. Крупнейшие горные системы - цепи Черского, Момский хребет, Лено-Чаунская горная дуга, Чукотское нагорье, горы Чукотского полуострова, средневысотные игоры правого берега реки Колымы.

В современном административно-государственном делении Северо-Восток интегрирует Магаданскую область, Камчатский край, Чукотский автономный округ, северо-восточные районы Республики Якутия (Саха). Магаданская область граничит со всеми указанными субъектами, на юге и юго-востоке омывается водами Охотского моря. Большая часть территории области занято тундрой и лесотундрой. Климат на большей части территории резко континентальный. Вся территория области, исключая побережье, находится в зоне многолетней мерзлоты. Площадь Магаданской области вместе с островами составляет 462,5 тыс. кв. км. Главная водная артерия - река Колыма.

Административно-территориальное деление российского Северо-Востока подвергалось многократным изменениям. Российское государство постепенно продвигало свои границы на восток. Особым в этом процессе стал XVII век. В силу комплекса внешних факторов и социально-экономических причин, сложившихся в России к XVII веку, вокруг страны сформировалось кольцо недружественных государств - Речи Посполитой, Швеции, Турции. Россия оказалась в экономической изоляции, отрезанной от торговых путей и источников торговли. Сама Россия с XVII века вступает в процесс формирования централизованного государства, что сопровождается усилением обмена между областями, ростом товарного обращения, 
складыванием всероссийского рынка. Закорномерным следствием развития русского централизованного государства явилась активизация поиска новых сырьевых баз и рынков сбыта. Таковыми могли стать обширные неизведенные территории Сибири и Дальнего Востока. Через Уральский хребет, образующий условную границу между Европой и Азией, на восток отправляются отряды казаков и промышленников, примкнувшим к ним «гулящих людей» - пассионарных пионеров фронтира. Цель отрядов - «прииск новых неясачных землиц», а также поиск серебряных месторождений для нужд государственной казны. Особый экономическай интерес представляла пушнина, являвшаяся ценным товаром, экспортируемым Россией. Приведенные под государеву руку сибирские народы платили ясак «мягкой рухлядью» и еe ежегодные поступления составляли значительную часть государственного бюджета. Для продвижения вперед и фиксирования присутствия, необходимы были опорные административно-военные точки, какими стали остроги.

В 1628 году была проведена разведка верховьев Лены отрядом под командованием Василия Бугра. В 1630 году в верховьях Лены закладывается первое русское укрепление - Ленский волок. В 1632 году сотником Петром Бекетовым в среднем течении реки на правом берегу Лены был заложен Ленский острог, впоследствии переименованный в Якутск. В Москве было принято решение создать самостоятельную административную единицу - Якутский уезд. Формирование приказно-воеводской системы государственного управления на Руси проходило вместе с процессами усиления власти великого князя и централизацией. Высшим органом власти была постоянно действующая Боярская Дума - аристократический совещательный орган, в который входили светские и духовные феодалы. Отраслевыми органами управления были приказы, совмещавшие административные и судебные функции. Позже возникли территориальные приказы, управлявшие отдельными регионами. Местное управление основывалось на системе кормлений. В период с 1599 по 1637 гг. сибирские земли находились под юрисдикцией Приказа Казанского Дворца (Казанского приказа), который осуществлял административно-судебное и финансовое управление землями восточных окраин государства. В 1637 году был выделен Сибирский приказ, в подчинение которого была передана территория всей Сибири - это свидетельствовало о понимании на правительственном уровне особенностей территории. Административно-территориальное и местное управление в Сибири в общем соответствовало общероссийской модели. Разряды делились на уезды, уезды подразделялись на низовые территориально-административные объединения - волости. Отличительной чертой сибирского управления было выделение особых единиц ясачных волостей, состоявших из улусов, наслегов, стойбищ. Администрации ясачных волостей имели большую автономию от центра, русская администрация не вмешивалась во внутреннее управление, отношения строились на основе обычного права. Сибирский приказ выполнял административные, судебные, финансовые, военные функции, ведал торговыми, ямскими, горно-рудными вопросами, частично посольскими сношениями с сопредельными с Сибирью странами, руководил сбором ясака. Приказу были подотчетны местные администрации. В конце XVII в. приказ состоял из Тобольского, Томского, Ленского и Мангазейского столов. Помимо столов в приказ были включены палаты (Расценочная, Купецкая, Казенная), ведавшие хранением и реализацией продуктов натуральных ясачных сборов. В состав Сибирского приказа помимо приказных служилых людей (судей приказа, дьяков, 
подъячих, писцов) входили ежегодно избираемые из именитых московских купцов целовальники, несшие материальную ответственность за сохранность пушной казны. Их деятельность не оплачивалась, считалась казенной службой. Для обработки меха в штат Сибирского приказа включались скорняки.

В 1638 году было основано Якутское воеводство (уезд), ставшее плацдармом для продвижения на Северо-Восток. Якутский уезд подчинялся Сибирскому приказу. Столица уезда - Якутский острог. Значительную роль в процессе колонизации Сибири сыграл этот опорный пункт. Ленский острог- Якутск стал важным русским укреплённым пунктом на Лене, благодаря чему казаки присоединили в дальнейшем весь северо-восток Сибири. До 1638 года Ленский острог подчинялся енисейской воеводской канцелярии и начальствовали в нём служилые чины, присланные из Енисейска. В 1638 году Якутск становится административным центром ВосточноСибирского воеводства. Воеводами были назначены Петр Головин и Матвей Глебов. Правительством перед ними были поставлены задачи расширения территории Московского государства на север и юго-восток Сибири, изыскание источников снабжения русского населения Сибири хлебом и поиск металлических руд. Якутское воеводство в период своего максимального территориального расширения охватывало бассейн реки Лены, включало побережье Охотского моря, Чукотский полуостров, Камчатку и, в определенный период, Забайкалье. Главой воеводства назначался воевода, который осуществлял обширные властные полномочия через приказчиков и якутских казаков, которые размещались в острогах и выполняли административные, исследовательские, завоевательные или карательные функции. Объем полномочий воеводы закреплялся в особых документах- наказах. Основные функции воеводы - сбор ясака и таможенных пошлин, управление служилыми людьми, коренным населением, судебные полномочия. Постепенно увеличивался административный штат воеводств. Для выполнения административных функций в подчинении у воеводы был дьяк (первый помощник, назначался из Москвы, руководил приказной избой), подьячие (назначались воеводой, работали в столах приказной избы). Местное население территорий вело традиционное хозяйство и было обязано платить ясак. Приведение коренного населения осваиваемых территорий «под государеву руку» далеко не всегда было мирным. Для гарантии оплаты ясака администрации приходилось брать аманатов (заложников), выдерживать осаду зимовий, вступать в прямые вооруженные столкновения с коренным населением.

По мере продвижения на восток, постепенно осваивались и Колымские территории. Михаил Стадухин поставил в 1645 г. в устье Колымы Нижне-Колымское ясачное зимовье. В 1646 году в Нижне-Колымский острожек прибыли промысловики «рыбьего зуба» (моржового клыка), сырья, успешно кункурировавшего со слоновой костью. В результате похода Семена Дежнева на Анадырь, в 1649 году был заложен Анадырский острог. Первый якутский воевода- Петр Петрович Головин (1639-1644 гг.) Основываются главные опорные остроги Якутского воеводства - Анадырский острог (1649), Верхоянск (1638), Вилюйск (1634), Жиганск (1632), Зашиверск (1639), Колымский острог (1634), Олекминск (1635),Охотск (1647), Нижне-Камчатский острог (1697).

На территории современной Магаданской области первым поселением русских стало Монтыклейское зимовье (третье по счету поселение русских на Охотском побережье). Зимовье было основано отрядом казаков под командованием А.Ф. 
Глубокого в месте впадения реки Монтыклейка в Монтыклейский залив в августе 1648 года. Просуществовало зимовье 3 года в условиях весьма враждебного отношения местных тунгусов, казаки «нужду, голод и бедность терпели». В июле 1651 года оставшиеся в живых казаки Монтыклейского зимовья вернулись в Охотский острог, собрав значительный ясак. В 1652 году Охотский острог был сожжен тунгусским отрядом. В октябре 1653 года к месту сожженного Охотского острога прибыл отряд казаков во главе с Андреем Булыгиным. Казаками был отстроен новый «ясачный острожек» с «государевым анбаром», «аманацкой казенкой», судной избой и жилищем для гарнизона. Назначение строений острожка соответствовало реализуемым административным и фискальным функциям - в судной избе служилые люди подавали челобитные на имя государя. В «аманацкой казенке» содержались заложники: «аманатов изымал и под государеву царскую высокую руку по их вере к шерте (клятве) их привели, чтобы они впредь государю были покорны в вечном холопстве». Из острожного «государева анбара» А. Булыгиным в 1653 году в Якутский острог было послано «государевой казны ясачного збору 6 сороков 24 соболи да лисицы чернобурую вешную, да лисицу сиводушную, да напольник соболей, а в нем пять пластин». Иерархическая система уездного управления на территории Северо-Востока во второй половине XVII- начале XVIII веков выглядела следующим образом: Сибирский приказ $\rightarrow$ приказная изба $\rightarrow$ столы (денежный, ясачный, разрядный, хлебный) $\rightarrow$ казачьи гарнизоны (остроги, зимовья).

Огромные просторы государства, дисперсность проживания населения на северных территориях требовали постоянного поиска наиболее эффективной модели администрирования. (Отметим, что актуальность данного вопроса высока и сегодня, и исторический опыт может быть полезен при решении и современных задач административно-территориального устройства). К началу XVIII в. действавшая в государстве система административного деления устарела. Отношения центрпровинция были запутанными, управление уездами, имевшими крайне неравномерные площади, было громоздким. Кроме этого, для успешного ведения Северной войны, стране требовалась новая система финансового и материального обеспечения армии и флота. Указом Петра I от 18 (29) декабря 1708 г. в государстве началась областная (губернская) реформа. Территория государства разбивалась на восемь губерний, возглавляемых губернаторами. На губернаторов были возложены административные, полицейские, финансовые, судебные функции, командование войсками в подведомственных губерниях. Первоначально (1710) губернии подразделялись на доли, с 1719 г.- на провинции, позднее - на дистрикты. Северо-восточные территории вошли в состав Сибирской губернии, столицей которой стал город Тобольск. По указу императора Сибирская губерния включала три провинции: Вятскую, Соликамскую и Тобольскую. В ноябре 1724 г. из состава Тобольской провинции были выделены Енисейская и Иркутская провинции. Якутский уезд вошел в состав Иркутской провинции. Иркутская провинция охватывала территории верховьев реки Лены, бассейн Колымы, Охотоморское побережье, Анадырский край, полуостров Камчатку. Сибирский приказ был преобразован в Московскую канцелярию Сибирской губернии и с 1710 г. фактически перестал существовать как центральное государственное учреждение. Его прежние функции выполнялись губернской канцелярией в г. Тобольске, возглавляемой сибирским губернатором. Дальнейшее административное развитие территорий Северо-Востока свидетельствует о поиске оптимальных форм 
соотношения центральной власти и местной администрации. Однако громадные просторы Сибири и Дальнего Востока не позволяли системе управления работать эффективно.

\section{***}

1. Север Дальнего Востока. - М.: Наука,1970.- С. 21,55; Дальний Восток. Физико-географическая характеристика.- М.: Изд-во АН СССР,1961.- С.91.

2. История отечественного государства и права: учебник / отв. ред. И. А. Исаев. - Москва: Проспект, 2012. - c. 62-63.

3. Административно-территориальное устройство Сибири и Дальнегшо Востока// «Историческая энциклопедия Сибири» 2009- Электронный ресурс http://irkipedia.ru/content/administrativno_territorialnoe_ustroystvo_sibiri_i_dalnego_vostoka_istoriches kaya Дата обращения 02.07.2017.

4. Сибирский приказ// «Историческая энциклопедия Сибири» 2009- Электронный ресурс http://irkipedia.ru/content/sibirskiy_prikaz_istoricheskaya_enciklopediya_sibiri_2009 . Дата обращения 01.07.2017.

5. Рябов Н.И., Штейн М.Г. Очерки истории русского Дальнего Востока XVII - начало XX века.Хабаровск: Хабаровское книжное издательство. 1958. - с. 24.

6. Лебединцев А.И. Начало освоения русскими землепроходцами северного побережья Охотского моря// История, археология и этнография Северо-Востока России. Магадан: СВКНИИ ДВО РАН, 1999.- C. 5-12.

7. Отписка Андрея Булыгина о походе на поберенжье Охотского моря//Записки древнерусских путешественников XVI-XVII вв./Сост., подгот. текстов, коммент. Н.И. Прокофьева, Л.И. Алехиной.- М.: Сов. Россия, 1988.- С. 412-413. 